Article

\title{
Importance of Chiral Recognition in Designing Metal-Free Ligands for G-Quadruplex DNA
}

\author{
Dora M. Răsădean, Samuel W. O. Harrison, Isobel R. Owens, Aucéanne Miramont, \\ Frances M. Bromley and G. Dan Pantoș *D
}

Department of Chemistry, University of Bath, Claverton Down, Bath BA2 7AY, UK;

D.Rasadean@bath.ac.uk (D.M.R.); swoharrison@gmail.com (S.W.O.H.); isobelowens1@gmail.com (I.R.O.);

a.miramont@escom.fr (A.M.); francesbromley95@gmail.com (F.M.B.)

* Correspondence: g.d.pantos@bath.ac.uk; Tel.: +44-1225-384-376

Academic Editor: Danzhou Yang

Received: 21 December 2018; Accepted: 11 April 2019; Published: 15 April 2019

\begin{abstract}
Four pairs of amino acid-functionalized naphthalenediimide enantiomers (D- and L-lysine derived NDIs) were screened toward G-quadruplex forming sequences in telomeres (h-TELO) and oncogene promoters: c-KIT1, c-KIT2, k-RAS and BCL-2. This is the first study to address the effect of point chirality toward G-quadruplex DNA stabilization using purely small organic molecules. Enantioselective behavior toward the majority of ligands was observed, particularly in the case of parallel conformations of c-KIT2 and k-RAS. Additionally, $N_{\varepsilon}$-Boc-L-Lys-NDI and $N_{\varepsilon}$-Boc-D-Lys-NDI discriminate between quadruplexes with parallel and hybrid topologies, which has not previously been observed with enantiomeric ligands.
\end{abstract}

Keywords: circular dichroism; G-quadruplex DNA; chirality; enantioselectivity; chiral recognition

\section{Introduction}

The demand for alternative approaches to the classical chemotherapy as principal treatment of cancer has led to the development of advanced techniques, and to the identification of new targets [1]. Among these, G-quadruplex DNA (G4 DNA) has emerged as a promising target as it is over-expressed in the promoter regions of a wide number of oncogenes as well as telomeres [2-4]. DNA sequences that are sufficiently rich in guanine $(G)$ have the ability to self-assemble into four stranded G-quadruplex (G4) structures [4]. The main structural component of G4 DNA is a planar arrangement of four guanines held together by cyclic Hoogsteen hydrogen bonding networks [5] (Figure 1). The directionality of the strands defines the folding topology as parallel, antiparallel, or a hybrid conformation [6], as illustrated in Figure 1. The type of conformation adopted by sequences is driven by a monovalent cation, which co-ordinates to the O6 oxygen of each $\mathrm{G}$ and thus stabilizes the G4 [4,7,8]. G4 DNA governs several vital biological processes such as transcription, translation and replication $[9,10]$, which makes it a promising target for anticancer therapies.

There is direct evidence that small ligands can suppress gene transcription, and therefore induce apoptosis [11]. However, the structural and topological diversity of quadruplexes and ligand-binding specificity remain key challenges in developing effective and selective G4 DNA-binding ligands [12]. A considerable number of small ligands have been developed as potential G4 binders, including Telomestatin ${ }^{\circledR}$, porphyrinoids, quinolones, alkaloids, carbazoles, acridine derivatives [13-26], and recently, reductive-activated G4-binders [27]. Besides ligands that have a planar surface for interaction with G4 DNA, molecules containing bi-aryl linkages have also emerged recently as promising candidates [28-31]. Representative examples include: phenanthroline-bisoxazoles [31], pentaheteroaryls [28], oxazoles [29], and oligomeric pyridyl-oxazoles [30] ligands. However, only one candidate—Quarfloxin ${ }^{\circledR}$ — has advanced to Phase II clinical trials albeit unsuccessfully [32]. 
(b)

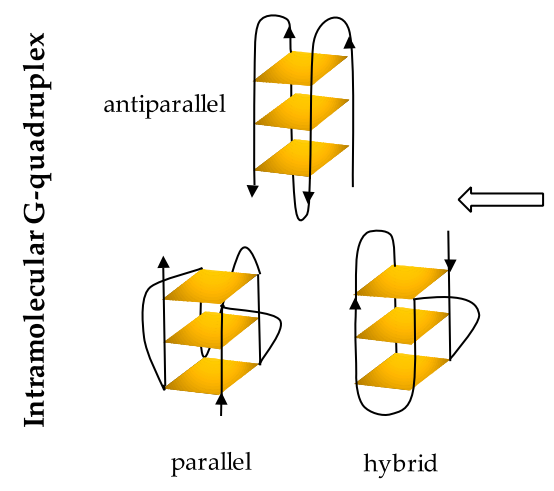

(a)

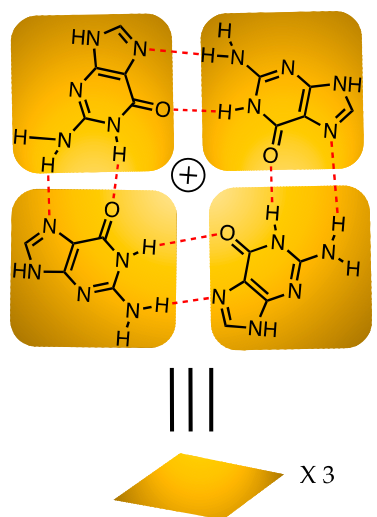

(c)

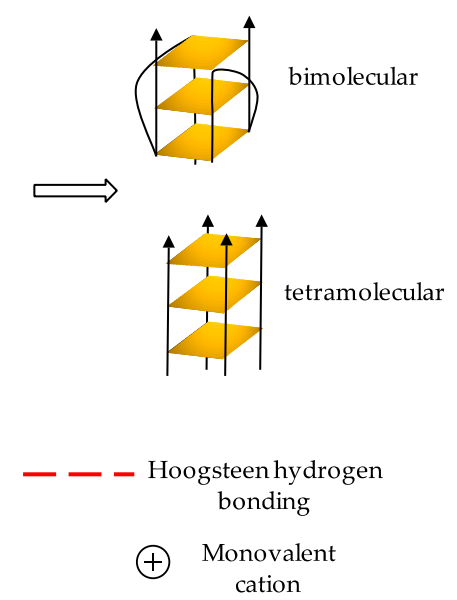

Figure 1. (a) Schematic representation of the structural unit of G-quadruplex DNA held together by a cyclic Hoogsteen hydrogen bonding network stabilized by monovalent cations; cartoon representations of: (b) intramolecular and (c) intermolecular topologies adopted by G-quadruplex DNA (G4 DNA). Arrow direction is from $5^{\prime}$ to $3^{\prime}$.

A scaffold that has attracted interest as potential G4 DNA-binding ligand is naphthalenediimide (NDI). NDI-based molecules consist of a large, planar and heteroaromatic surface that can interact with G4 DNA via aromatic $\pi-\pi$ stacking $[33,34]$. The literature reports di-, tri-, and tetra-substituted NDI ligands with high affinity for G4 [8,9,35-41]. We have recently reported the synthesis of symmetrical di-substituted NDIs bearing amino acids as peripheral substituents [35]. One of the ligands $\left(N_{\varepsilon}\right.$-Boc-L-Lys NDI, see Figure 2$)$ has exhibited a highly discriminating nature by stabilizing only the oncogene promoter c-KIT2 [35].

(a)
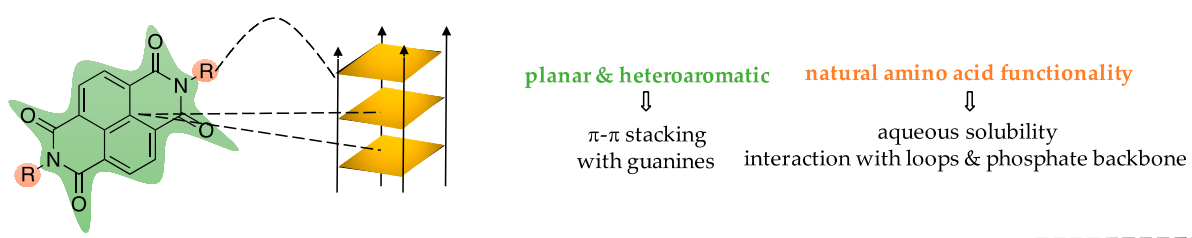

(b)
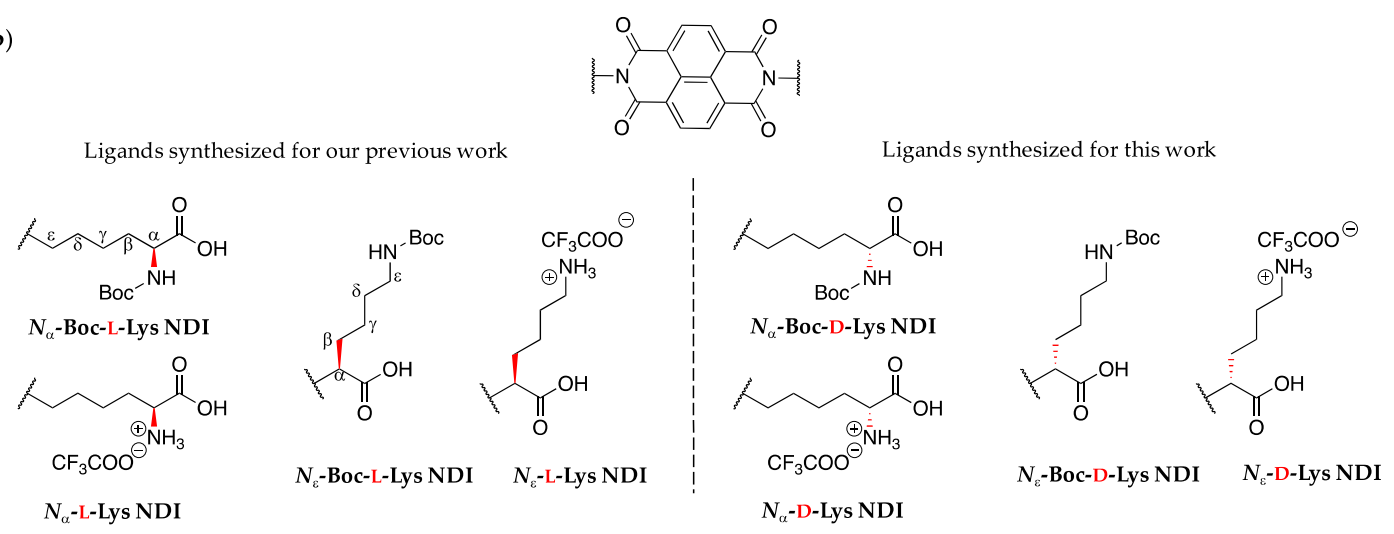

$$
\text { вос }=\text { 닝 } K
$$

Figure 2. (a) Structural features of naphthalenediimide (NDI) molecules synthesized and interaction with G4 DNA; (b) chemical structures of L-NDIs (left) and D-NDIs (right) used in our studies and their corresponding names. The naming is based on the position of the carboxylic acid relative to the NDI core: either distal ( $N_{\alpha}$-Lys NDIs) or proximal ( $N_{\varepsilon}$-Lys NDIs). The L or D chirality is highlighted in red. 
One of the key features of the series of NDIs we have previously reported is their chiral nature, which was not discussed in detail in our previous study. Chirality is ubiquitous in nature and plays crucial roles in drug design [42,43], thus we decided to explore the influence of chirality on the interaction of our NDI-based ligands with G4 DNA. It is widely known that enantiomers can display different biological activity on the basis of toxicology, pharmacology, pharmacokinetics and metabolism [42]. To the best of our knowledge, all chiral G4-ligands explored so far are metal-containing, and can be categorized into either metallo-supramolecular assemblies [44-46] or complexes with transition metals $(\mathrm{Ru}, \mathrm{Cu}, \mathrm{Ni}, \mathrm{Fe}, \mathrm{Zn}, \mathrm{Pt})$ [47-57]. A recently reported study on metallohelices and enantiomeric G-quadruplex DNA showed an interesting mirror-image dependence of ligands binding to L- or D-DNA [58]. Although point chirality is present in Telomestatin ${ }^{\circledR}$ (a natural product) and Quarfloxin ${ }^{\circledR}[32,51,59]$, no account or consideration of the significance of point chirality/enantiomeric forms is given in the literature.

The current study comes as a complementary work on the series of L-NDIs we have recently reported [35], thus references to this will be made throughout this manuscript. This work highlights the significance of point chirality toward stabilization of G4 within telomeres (h-TELO) and oncogene promoter regions k-RAS, c-KIT and BCL-2. The k-RAS sequence is dis-regulated in pancreatic cancer [9], while c-KIT2 is upregulated up to $80 \%$ in breast malignancies [60]. BCL-2 is highly expressed in androgen-independent tumors in advanced states of prostate cancer [61,62]. BCL-2 is also dis-regulated in pancreatic cancer; therefore, BCL-2 has emerged as an important target for both prostate and pancreatic cancers therapies [61,62]. We have changed the chirality from L- to D-enantiomers of lysine-functionalized NDIs and have explored their potential as G4 DNA as well as dsDNA binders. The interaction with the latter must be very small so that any G4 DNA potential ligands do not affect the dsDNA present in healthy cells. This work paves the way for understanding the importance of chiral recognition in designing efficient ligands for G4 DNA.

\section{Results and Discussion}

\subsection{Ligand Design}

The NDI scaffold is an attractive platform for designing G4 ligands due to the electron-deficient polyaromatic core that can stack on the guanine tetrads. We have chosen lysine (Lys) due to its ideal structural features to interacting with G-quadruplex DNA. Lys functionalization imparts water solubility and positive charges that can interact with the DNA's phosphate backbone. Our previous work indicated that the length of peripheral substituents played a role in binding [35]. Lys showed best binding (and selective behavior) for certain quadruplexes [35]. The key features that make these NDIs potential G4 DNA binders are highlighted in Figure 2a.

This study is focused on the influence of chirality on the G4-ligand interaction. The chemical structures of the Lys-NDI derivatives are provided in Figure $2 \mathrm{~b}$. The ligands can be categorized depending on: (1) Lys connectivity, where $\alpha$-corresponds to the stereocentre distal from the NDI core, while $\varepsilon$-represents a structure with the stereocentre proximal to the NDI core; and (2) presence or absence of the $\mathrm{N}$-Boc protecting group of the amine functionality. The synthetic route assumed a one-step microwave-assisted reaction (for Boc-protected NDIs), followed by a classic deprotection with trifluoroacetic acid (TFA) to yield the deprotected derivatives [35,63].

All experiments were performed in PBS (phosphate-buffered saline, $10 \mathrm{mM}$ ) containing $100 \mathrm{mM}$ of potassium fluoride at $\mathrm{pH} 7.4$ (as source of cations) in order to resemble the physiological conditions. Although slightly lower than generally found in cells [64], the $\mathrm{K}^{+}$concentration provides the fundamental cation channel for quadruplex formation.

\subsection{G4 DNA Topology Analysis}

G4 DNA is known to adopt different conformations depending on the conditions in which the annealing is performed. The folding topologies of the sequences used in this work were determined by 
circular dichroism (CD) analysis (CD spectra of all sequences are provided in Supplementary Material, Figure S1), and are in agreement with previously reported information [35]. The CD profile of k-RAS and c-KIT2 in PBS at pH 7.4 displayed characteristics of a parallel topology, with large positive Cotton effects around $260 \mathrm{~nm}$, and smaller negative peaks at shorter wavelengths. The folding of k-RAS and c-KIT2 into parallel conformations is consistent with other studies reported in the literature [6,65-68]. The only telomeric sequence in this study-h-TELO—folded in a hybrid manner, and its CD fingerprint was characterized by a positive peak at $290 \mathrm{~nm}$ and a small negative peak at $260 \mathrm{~nm}$. Previously reported studies also confirm the hybrid arrangement of h-TELO forming-quadruplex DNA [69-74]. The CD spectra of c-KIT1 and BCL-2 exhibited spectral features corresponding to parallel topologies. However, they showed small and positive shoulder peaks around $290 \mathrm{~nm}$, indicating the hybrid character of these two sequences under these particular experimental conditions (3:1 parallel to antiparallel ratio) (see Supplementary Material, Figure S1d). c-KIT1 has been previously reported as folding into mixed parallel:antiparallel conformation under $\mathrm{K}^{+}$conditions [75]. BCL-2 sequence can form either a hybrid or a 1:13:1 parallel structure, depending on the length and type of nucleobases [76-84]. The BCL-2 fragment used in this study folds into a hybrid structure, as confirmed by CD studies. The only non-quadruplex forming sequence-dsDNA — was characterized by a positive peak at $272 \mathrm{~nm}$ and a large negative peak around $250 \mathrm{~nm}$. Quadruplex topology was retained on addition of ligand; however, it was accompanied by a minor shift of $1-3 \mathrm{~nm}$ and reduced peak intensity [31]. The G-quadruplex sequences do not change their conformation upon NDIs binding, as indicated by CD spectra before (Figures S3-S9) and during (Figure S10) variable-temperature (VT) CD studies (without and with ligands; further details in Supplementary Materials). To further show this, CD titration studies of increasing equivalents of ligand into DNA were performed (Figure S11).

\subsection{Thermal Melting Studies}

The stabilization effect of the NDI ligands toward a panel of G4 DNA sequences (k-RAS, c-KIT1, c-KIT2, BCL-2, h-TELO) as well as dsDNA was investigated by performing VT CD studies. The melting, or denaturation, of DNA is characterized by the loss of $\mathrm{CD}$ response, and the melting temperature $\left(T_{\mathrm{m}}\right.$, reported in ${ }^{\circ} \mathrm{C}$ ) is defined as the equilibrium state at which $50 \%$ of the DNA is folded and $50 \%$ unfolded. The profile of a CD melting curve gives information on the progress of DNA denaturation as temperature is increased. The $T_{\mathrm{m}}$ of G4 DNA-NDI complexes is directly linked with the number of available binding sites, binding fashion and the affinity of each ligand for a particular topology. DNA can melt in either a single-step denaturation, showing isosbestic points, or a concerted process, in which multiple stable intermediates can be observed.

The VT CD experiment design involved the addition of 10 equivalents of ligand to the DNA sequence solution and sequential CD data acquisition over a 5-95 ${ }^{\circ} \mathrm{C}$ temperature range. The Boc-protected NDI ligands are soluble in aqueous solution, while the deprotected ones are prone to aggregation. Therefore, solutions of all ligands in PBS were prepared at concentrations of $300 \mu \mathrm{M}$, except for $N_{\mathcal{\varepsilon}}$-D-Lys NDI, concentration of which was $75 \mu \mathrm{M}$. The reported melting temperatures of DNA interacting with $N_{\mathcal{\varepsilon}}$-Lys NDI represent a combination of the temperature induced de-aggregation of $N_{\mathcal{\varepsilon}}$-Lys NDI and the ligand-DNA binding processes.

The melting profile of each G4 DNA-NDI complex was monitored at a single-wavelength, allowing a larger number of data points to be obtained in the same (or shorter) timeframe compared to measuring across the entire wavelength range. The relevant single-wavelength for VT CD analysis was selected by acquiring a CD spectrum across the wavelength range $220-420 \mathrm{~nm}$; the wavelength corresponding to the DNA peak with maximum ellipticity $\left(\lambda_{\max }\right)$ was chosen. The data was fitted using the Boltzmann mathematical model; the $T_{\mathrm{m}}$ was determined as the midpoint of the sigmoidal melting curve. The stabilization effect of the NDIs toward the DNA sequences is defined by the difference in melting temperature $\left(\Delta T_{\mathrm{m}}\right.$, also reported in $\left.{ }^{\circ} \mathrm{C}\right)$ between the ligand/DNA complex and the DNA by itself. A positive $\Delta T_{\mathrm{m}}$ indicates that the melting temperature has increased, and thus the ligand has stabilized the DNA sequence under the experimental conditions used. 
The results are discussed in terms of mean $\Delta T_{\mathrm{m}}$ and in conjunction with those obtained from the L-NDI series of ligands [35]. This allows comparison between the stabilization effect of the pair of enantiomers (i.e., $\alpha$ - and $\varepsilon$-connectivities as well as protected/deprotected versions for both $\mathrm{L}$ - and D-isomers) toward G4 DNA-forming sequences and dsDNA. The errors of $T_{\mathrm{m}}$ values in the case of L-NDIs are larger compared to those from D-ligands because of different number of data points obtained in each experiment: $\sim 19$ for L-NDIs and $\sim 90$ for D-NDIs. This affects mainly the sequences exhibiting high $T_{\mathrm{m}}$ such as c-KIT1 and c-KIT2. However, the data obtained for $\mathrm{L}^{-} \mathrm{vs}$. D- will be used to illustrate the direction the ligand influences the DNA (i.e., stabilisation/destabilisation). In the case of BCL-2, both L-Lys and D-Lys NDI derivatives have been investigated, as the BCL-2 sequence was not part of our original screen.

\subsection{1. c-KIT2}

The $N_{\mathcal{E}}$-Boc-L-Lys NDI stabilizes c-KIT2 by almost $15{ }^{\circ} \mathrm{C}$, while a $10{ }^{\circ} \mathrm{C}$ stabilization was observed for its $\alpha$-connectivity counterpart ( $N_{\alpha}$-Boc-L-Lys NDI) [35]. Remarkably, their enantiomers, $N_{\varepsilon}$-Boc-D-Lys NDI and $N_{\alpha}$-Boc-D-Lys NDI, have very little interaction with c-KIT2 $\left(\Delta T_{\mathrm{m}}=-1.6\right.$ and $+1.4^{\circ} \mathrm{C}$, respectively; Figure $3 \mathrm{a}$ and Table $1 \mathrm{a}$. This finding is very important as it shows, for the first time, that enantiomeric ligands have different strength of interaction with a quadruplex DNA, namely c-KIT2. Therefore, the difference in point chirality between the two ligands imposes a "matched" interaction with the binding site of c-KIT2 in the case of L-NDI, whereas the interaction with the opposite three-dimensional structure is not favorable. The larger difference in stabilization between the $\varepsilon$ - enantiomers vs. $\alpha$ - enantiomers emphasizes that the closer the point chirality to the NDI core, the higher selectivity in binding is observed. In the case of $\varepsilon$-connectivity derivatives, the chiral center is close to the NDI core (thus the selective interaction), while the $\alpha$-NDIs have the chiral center five bonds away from the core. The $\varepsilon$-deprotected versions of both enantiomers exhibited destabilization toward c-KIT2, while the NDIs with $\alpha$-connectivity showed favorable, but less selective interaction with its structure (Figure $3 b$ and Table $1 b$ ). The VT CD single-wavelength spectra of c-KIT2 by itself as well as c-KIT2-NDI assemblies and their corresponding Boltzmann fitting curves are illustrated in Supplementary Material, Figure S12.

(a)

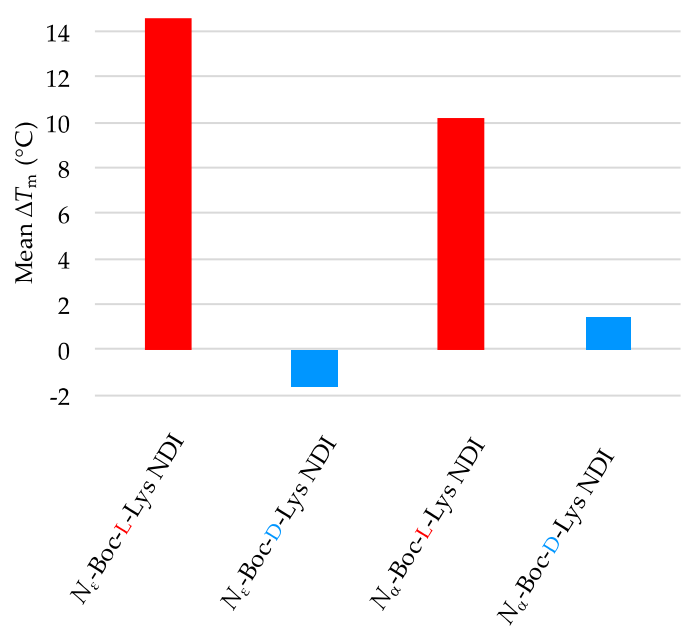

(b)

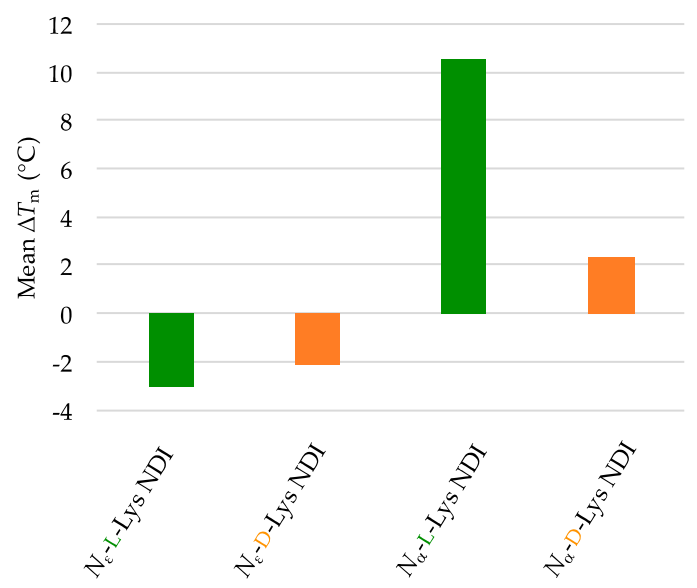

Figure 3. Graphical representations of mean $\Delta T_{\mathrm{m}}$ values obtained from variable-temperature circular dichroism (VT CD) studies of c-KIT2 with 10 equivalents of (a) $N_{\alpha}$ - and $N_{\varepsilon}$-Boc-L- and D-NDIs as well as (b) $N_{\alpha}$ - and $N_{\mathcal{E}}$-L- and D-NDIs. 
Table 1. The $T_{\mathrm{m}}$ values of c-KIT2 only compared to the $T_{\mathrm{m}}$ of (a) c-KIT2-Boc-protected-NDIs and (b) c-KIT2-deprotected-NDIs as determined from VT CD studies.

\begin{tabular}{lc|cc}
\hline (a) & \multicolumn{3}{|l}{ (b) } \\
\hline Sequence/Assembly & $\boldsymbol{T}_{\mathbf{m}}\left({ }^{\circ} \mathbf{C}\right)$ & Sequence/Assembly & $\boldsymbol{T}_{\mathbf{m}}\left({ }^{\circ} \mathbf{C}\right)$ \\
\hline c-KIT2 only & $78.2 \pm 2.7^{\mathrm{a}} / 78.9 \pm 0.8^{\mathrm{b}}$ & $\mathrm{c}-\mathrm{KIT} 2$ only & $78.2 \pm 2.7^{\mathrm{a}} / 78.9 \pm 0.8^{\mathrm{b}}$ \\
$N_{\varepsilon}$-Boc-L-Lys NDI & $92.8 \pm 5.9$ & $N_{\varepsilon}$-L-Lys NDI & $75.1 \pm 0.9$ \\
$N_{\varepsilon}$-Boc-D-Lys NDI & $77.3 \pm 0.4$ & $N_{\varepsilon}$-D-Lys NDI & $76.8 \pm 0.3$ \\
$N_{\alpha}$-Boc-L-Lys NDI & $88.4 \pm 8.4$ & $N_{\alpha}$-L-Lys NDI & $88.7 \pm 7.1$ \\
$N_{\alpha}$-Boc-D-Lys NDI & $80.3 \pm 0.1$ & $N_{\alpha}$-D-Lys NDI & $81.2 \pm 1.0$ \\
\hline
\end{tabular}

${ }^{a}$ This value was used for calculating the $T_{\mathrm{m}}$ for all c-KIT2-L-NDIs assemblies; ${ }^{\mathrm{b}}$ This value was used for calculating the $T_{\mathrm{m}}$ for all c-KIT2-D-NDIs assemblies.

\subsection{2. c-KIT1}

Both enantiomers of $N_{\varepsilon}$-Boc-Lys NDI ligands discriminate between c-KIT1 and c-KIT2, even though they are putative $G 4$-forming sequences within the same promoter. The pair $N_{\varepsilon}-$ Boc-L-Lys $/ N_{\mathcal{\varepsilon}}$-Boc-D-Lys NDIs displayed an opposite stabilization behavior toward c-KIT1 compared to c-KIT2. While $N_{\varepsilon}$-Boc-L-Lys NDI destabilized the sequence by $-1.5^{\circ} \mathrm{C}$, its enantiomer induced a minor stabilization of $1.5^{\circ} \mathrm{C}$. Both $\alpha$-protected enantiomers exhibited small stabilization of c-KIT1 hybrid structure. As in the case of c-KIT2, chiral recognition of the $\varepsilon$-connectivity ligands was observed. All deprotected NDIs show minor stabilization $\left(<2{ }^{\circ} \mathrm{C}\right)$, indicating that the ligands interact weakly with the DNA. The mean $\Delta T_{\mathrm{m}}$ obtained from VT CD studies of c-KIT1 with NDI ligands are graphically represented in Figure $4 \mathrm{a}, \mathrm{b}$, and the $T_{\mathrm{m}}$ values of c-KIT1 as well as c-KIT1-NDI assemblies are provided in Table 2a,b. The VT CD single-wavelength spectra of c-KIT1 by itself as well as c-KIT1-NDI assemblies and their corresponding Boltzmann fitting curves are shown in Supplementary Material, Figure S13.

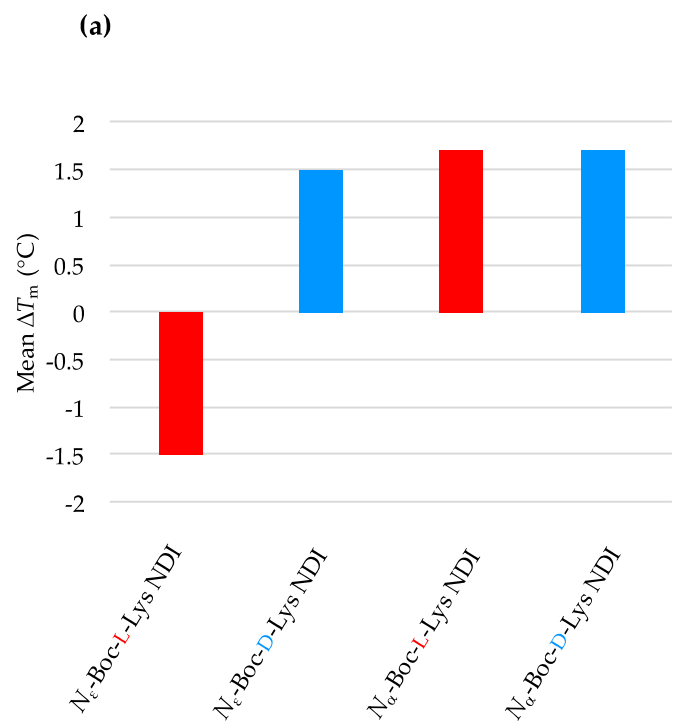

(b)

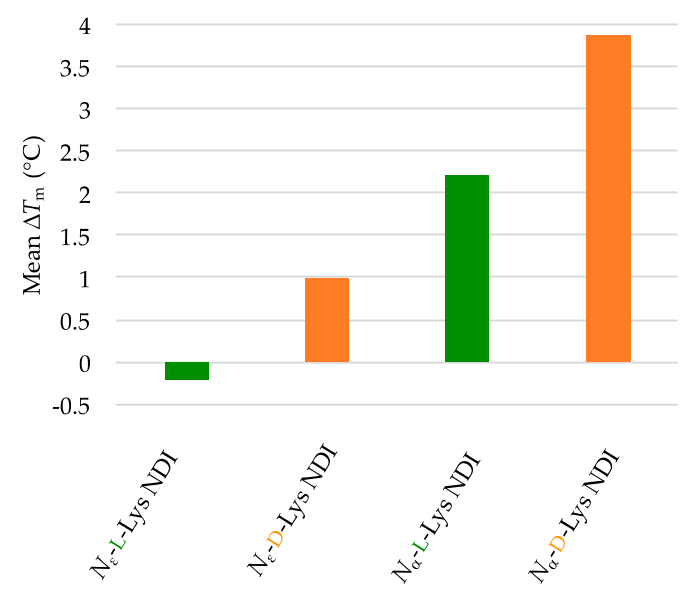

Figure 4. Graphical representations of mean $\Delta T_{\mathrm{m}}$ values obtained from VT CD studies of c-KIT1 with 10 equivalents of (a) $N_{\alpha}$ - and $N_{\mathcal{\varepsilon}}$-Boc-L- and D-NDIs as well as (b) $N_{\alpha}$ - and $N_{\mathcal{\varepsilon}}$ - L- and D-NDIs. 
Table 2. The $T_{m}$ values of c-KIT1 only compared to the $T_{m}$ of (a) c-KIT1-Boc-protected-NDIs and (b) c-KIT1-deprotected-NDIs as determined from VT CD studies.

\begin{tabular}{cc|cc}
\hline (a) & & (b) & \\
\hline Sequence/Assembly & $\boldsymbol{T}_{\mathbf{m}}\left({ }^{\circ} \mathbf{C}\right)$ & Sequence/Assembly & $\boldsymbol{T}_{\mathbf{m}}\left({ }^{\circ} \mathbf{C}\right)$ \\
\hline c-KIT1 only & $65.8 \pm 0.4^{\mathrm{a}} / 65.4 \pm 0.4$ & c-KIT1 only & $65.8 \pm 0.4^{\mathrm{a}} / 65.4 \pm 0.4^{\mathrm{b}}$ \\
$N_{\varepsilon}$-Boc-L-Lys NDI & $64.3 \pm 0.4$ & $N_{\varepsilon}$-L-Lys NDI & $65.6 \pm 0.7$ \\
$N_{\varepsilon}$-Boc-D-Lys NDI & $66.9 \pm 0.2$ & $N_{\varepsilon}$-D-Lys NDI & $66.4 \pm 0.2$ \\
$N_{\alpha}$-Boc-L-Lys NDI & $67.5 \pm 1.0$ & $N_{\alpha}$-L-Lys NDI & $68.0 \pm 0.8$ \\
$N_{\alpha}$-Boc-D-Lys NDI & $67.1 \pm 0.2$ & $N_{\alpha}$-D-Lys NDI & $69.3 \pm 0.3$ \\
\hline
\end{tabular}

${ }^{\text {a }}$ This value was used for calculating the $T_{\mathrm{m}}$ for all c-KIT1-L-NDIs assemblies; ${ }^{\mathrm{b}}$ This value was used for calculating the $T_{\mathrm{m}}$ for all c-KIT1-D-NDIs assemblies.

\subsection{3. k-RAS}

The oncogene promoter k-RAS adopts, under our experimental conditions, a parallel conformation with short loops. It has the lowest melting temperature of all DNA sequences used in this study. The melting profiles of k-RAS displayed characteristic sigmoidal curves, regardless of the ligand used. Good fitting of the Boltzmann mathematical model resulted melting studies with the lowest $T_{\mathrm{m}}$ errors. All Boc-protected ligands showed discriminating behavior toward k-RAS. Both $N_{\varepsilon}$-Boc-L-Lys and $N_{\alpha}$-Boc-L-Lys NDIs induced a minor stabilization on this sequence $\left(2{ }^{\circ} \mathrm{C}\right)$, while their enantiomers destabilized it. The position of the chiral center, proximal or distal, with respect to the NDI has little influence on the interaction with k-RAS, whereas the chirality of the stereocenter is the determining factor in the interaction between this quadruplex and the NDI ligands.

Similar behavior was observed for the deprotected ligands, with $N_{\varepsilon}$-L-Lys NDI moderately stabilizing k-RAS, and its enantiomer destabilizing it. The D-enantiomer of $\alpha$-NDI also has a stabilizing effect, but as this ligand is prone to aggregation, these results should be considered as a combination between ligand de-aggregation and interaction with the DNA. The results are provided as graphs in Figure $5 \mathrm{a}, \mathrm{b}$, and the $T_{\mathrm{m}}$ values of k-RAS as well as k-RAS-NDI assemblies are summarized in Table $3 \mathrm{a}, \mathrm{b}$. The VT CD single-wavelength spectra of k-RAS by itself as well as k-RAS-NDI assemblies and their corresponding Boltzmann fitting curves are depicted in Supplementary Material, Figure S14.

(a)

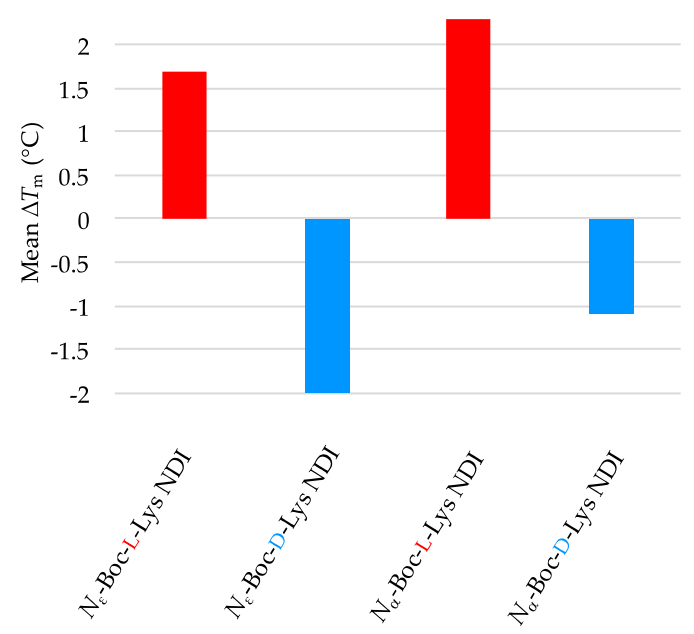

(b)

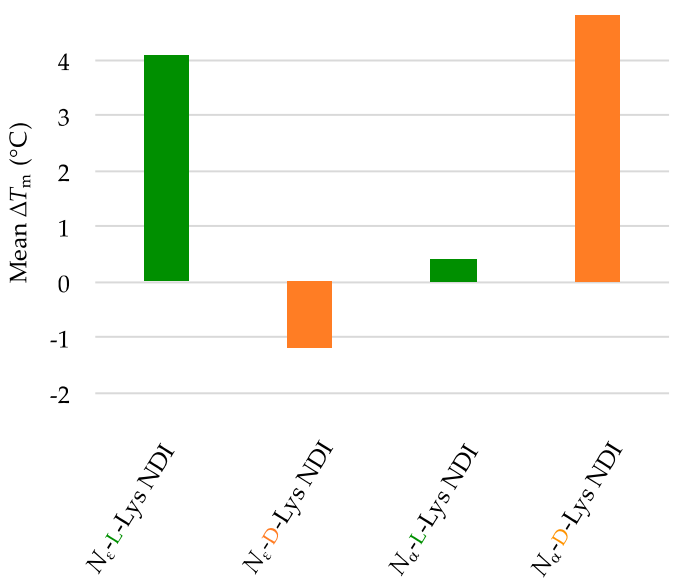

Figure 5. Graphical representations of mean $\Delta T_{\mathrm{m}}$ values obtained from VT CD studies of k-RAS with 10 equivalents of (a) $N_{\alpha}$ - and $N_{\mathcal{E}}$-Boc-L- and D-NDIs as well as (b) $N_{\alpha}$ - and $N_{\mathcal{E}}$-L- and D-NDIs. 
Table 3. The $T_{\mathrm{m}}$ values of k-RAS only compared to the $T_{\mathrm{m}}$ of (a) k-RAS-Boc-protected-NDIs and (b) k-RAS-deprotected-NDIs as determined from VT CD studies.

\begin{tabular}{cc|cc}
\hline (a) & & (b) & \\
\hline Sequence/Assembly & $\boldsymbol{T}_{\mathbf{m}}\left({ }^{\circ} \mathbf{C}\right)$ & Sequence/Assembly & $\boldsymbol{T}_{\mathbf{m}}\left({ }^{\circ} \mathbf{C}\right)$ \\
\hline k-RAS only & $58.3 \pm 0.6^{\mathrm{a}} / 55.8 \pm 0.1^{\mathrm{b}}$ & k-RAS only & $58.3 \pm 0.6^{\mathrm{a}} / 55.8 \pm 0.1^{\mathrm{b}}$ \\
$N_{\varepsilon}$-Boc-L-Lys NDI & $60.0 \pm 0.5$ & $N_{\varepsilon}$-L-Lys NDI & $62.4 \pm 0.4$ \\
$N_{\varepsilon}$-Boc-D-Lys NDI & $53.8 \pm 0.1$ & $N_{\varepsilon}$-D-Lys NDI & $54.6 \pm 0.1$ \\
$N_{\alpha}$-Boc-L-Lys NDI & $60.6 \pm 0.3$ & $N_{\alpha}$-L-Lys NDI & $58.7 \pm 1.1$ \\
$N_{\alpha}$-Boc-D-Lys NDI & $54.7 \pm 0.1$ & $N_{\alpha}$-D-Lys NDI & $60.6 \pm 0.1$ \\
\hline
\end{tabular}

${ }^{\text {a }}$ This value was used for calculating the $T_{\mathrm{m}}$ for all k-RAS-L-NDIs assemblies; ${ }^{\mathrm{b}}$ This value was used for calculating the $T_{\mathrm{m}}$ for all $\mathrm{k}$-RAS-D-NDIs assemblies.

\subsubsection{BCL-2}

The Boc-protected NDIs stabilized the BCL-2 sequence, except $N_{\varepsilon}$-Boc-L-Lys NDI, which showed minor destabilization of this sequence, as shown in Figure 6a and Table 4a. The best stabilization in the ligand series was induced by $N_{\alpha}$-Boc-L-Lys NDI, with a $\Delta T_{\mathrm{m}}$ of $9^{\circ} \mathrm{C}$. This sequence exhibits enantioselective interaction with the enantiomers with $\varepsilon$-connectivity (chiral center close the NDI unit): $N_{\varepsilon}$-Boc-L-Lys NDI stabilizes it, whereas its enantiomer does not. All the deprotected ligands have a stabilizing effect on BCL-2, with no selectivity L- vs. D-enantiomers, or $\alpha$ - vs. $\varepsilon$-connectivities (Figure $6 \mathrm{~b}$ and Table $4 \mathrm{~b}$ ). The VT CD single-wavelength spectra of BCL-2 by itself as well as BCL-2-NDI assemblies and their corresponding Boltzmann fitting curves are given in Material: Supplementary Material: Figures S15 (for L-NDIs) and S16 (for D-NDIs).

(a)

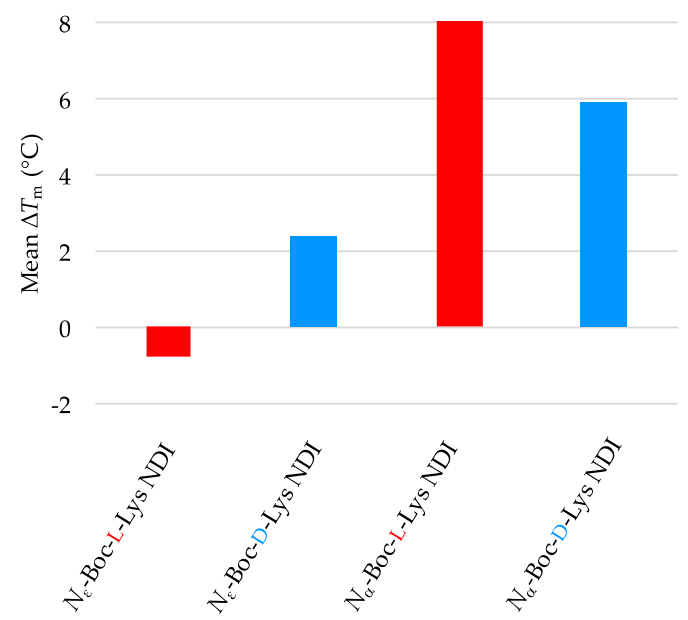

(b)

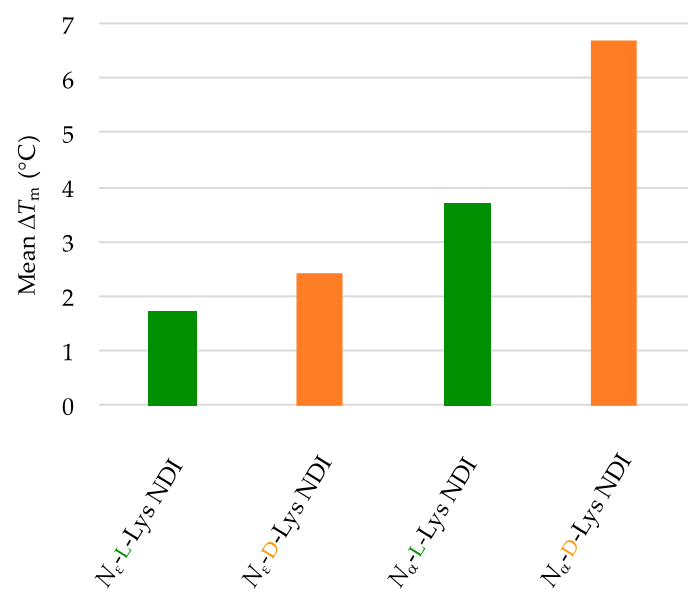

Figure 6. Graphical representations of mean $\Delta T_{\mathrm{m}}$ values obtained from VT CD studies of BCL-2 with 10 equivalents of (a) $N_{\alpha}$ - and $N_{\mathcal{\varepsilon}}$-Boc-L- and D-NDIs as well as (b) $N_{\alpha^{-}}$and $N_{\mathcal{E}^{-}}$-L- and D-NDIs.

Table 4. The $T_{\mathrm{m}}$ values of BCL-2 only compared to the $T_{\mathrm{m}}$ of (a) BCL-2-Boc-protected-NDIs and (b) BCL-2-deprotected-NDIs as determined from VT CD studies.

\begin{tabular}{lc|cc}
\hline (a) & & (b) & \\
\hline Sequence/Assembly & $\boldsymbol{T}_{\mathbf{m}}\left({ }^{\circ} \mathbf{C}\right)$ & Sequence/Assembly & $\boldsymbol{T}_{\mathbf{m}}\left({ }^{\circ} \mathbf{C}\right)$ \\
\hline BCL-2 only & $66.0 \pm 0.4^{\mathrm{a}} / 66.1 \pm 0.4^{\mathrm{b}}$ & BCL-2 only & $66.0 \pm 0.4^{\mathrm{a}} / 66.1 \pm 0.4^{\mathrm{b}}$ \\
$N_{\varepsilon}$-Boc-L-Lys NDI & $65.2 \pm 0.5$ & $N_{\varepsilon}$-L-Lys NDI & $67.7 \pm 0.4$ \\
$N_{\varepsilon}$-Boc-D-Lys NDI & $68.5 \pm 0.4$ & $N_{\varepsilon}$-D-Lys NDI & $68.5 \pm 0.3$ \\
$N_{\alpha}$-Boc-L-Lys NDI & $74.9 \pm 0.8$ & $N_{\alpha}$-L-Lys NDI & $69.7 \pm 1.0$ \\
$N_{\alpha}$-Boc-D-Lys NDI & $72.0 \pm 0.3$ & $N_{\alpha}$-D-Lys NDI & $72.8 \pm 0.3$ \\
\hline
\end{tabular}

${ }^{\text {a }}$ This value was used for calculating the $T_{\mathrm{m}}$ for all BCL-2-L-NDIs assemblies; ${ }^{\mathrm{b}}$ This value was used for calculating the $T_{\mathrm{m}}$ for all BCL-2-D-NDIs assemblies. 


\subsection{5. h-TELO}

The hybrid conformation h-TELO interacts weakly with the majority of NDI ligands studied. This suggests that this topology is poorly and non-selectively stabilized by Lys-functionalized di-substituted NDIs, which is consistent with the results obtained for also hybrid c-KIT1 and BCL-2 (except the $\varepsilon$-connectivity ligands). The results are graphically represented as mean $\Delta T_{\mathrm{m}}$ in Figure $7 \mathrm{a}, \mathrm{b}$. The $T_{\mathrm{m}}$ values of $\mathrm{h}$-TELO as well as h-TELO-NDI assemblies are listed in Table $5 \mathrm{a}, \mathrm{b}$. The VT CD single-wavelength spectra of h-TELO by itself as well as h-TELO-NDI assemblies and their corresponding Boltzmann fitting curves are provided in Supplementary Material, Figure S17.

(a)

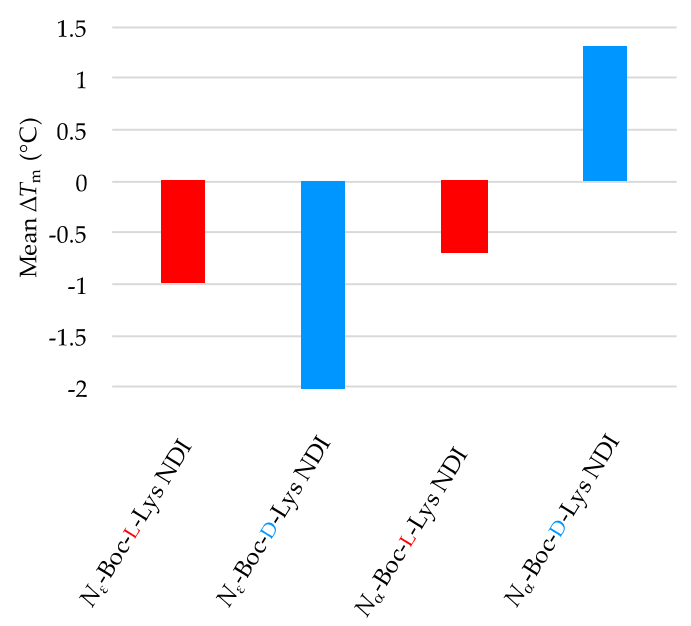

(b)

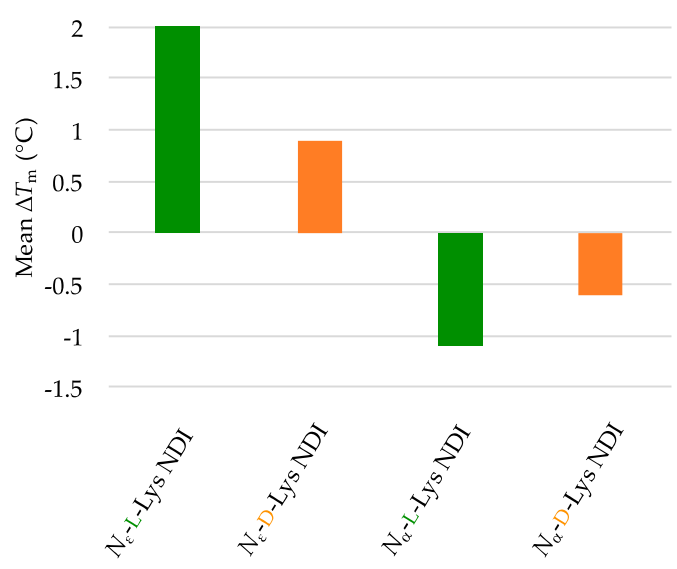

Figure 7. Graphical representations of mean $\Delta T_{\mathrm{m}}$ values obtained from VT CD studies of h-TELO with

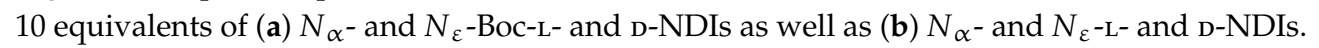

Table 5. The $T_{m}$ values of h-TELO only compared to the $T_{m}$ of (a) h-TELO-Boc-protected-NDIs and (b) h-TELO-deprotected-NDIs as determined from VT CD studies.

\begin{tabular}{cc|cc}
\hline (a) & & (b) & \\
\hline Sequence/Assembly & $\boldsymbol{T}_{\mathbf{m}}\left({ }^{\circ} \mathbf{C}\right)$ & Sequence/Assembly & $\boldsymbol{T}_{\mathbf{m}}\left({ }^{\circ} \mathbf{C}\right)$ \\
\hline h-TELO only & $62.5 \pm 0.3^{\mathrm{a}} / 65.8 \pm 0.1 \mathrm{~b}$ & h-TELO only & $62.5 \pm 0.3^{\mathrm{a}} / 65.8 \pm 0.1^{\mathrm{b}}$ \\
$N_{\varepsilon}$-Boc-L-Lys NDI & $61.5 \pm 0.6$ & $N_{\varepsilon}$-L-Lys NDI & $64.5 \pm 0.4$ \\
$N_{\varepsilon}$-Boc-D-Lys NDI & $63.2 \pm 0.1$ & $N_{\varepsilon}$-D-Lys NDI & $66.7 \pm 0.2$ \\
$N_{\alpha}$-Boc-L-Lys NDI & $61.8 \pm 0.4$ & $N_{\alpha}$-L-Lys NDI & $61.4 \pm 1.0$ \\
$N_{\alpha}$-Boc-D-Lys NDI & $67.1 \pm 0.1$ & $N_{\alpha}$-D-Lys NDI & $65.2 \pm 0.1$ \\
\hline
\end{tabular}

${ }^{\mathrm{a}}$ This value was used for calculating the $T_{\mathrm{m}}$ for all h-TELO-L-NDIs assemblies; ${ }^{\mathrm{b}}$ This value was used for calculating the $T_{\mathrm{m}}$ for all h-TELO-D-NDIs assemblies.

\subsection{6. dsDNA}

$N_{\alpha}$-D-Lys NDI largely destabilized dsDNA by around $5{ }^{\circ} \mathrm{C}$, while $N_{\alpha}$-Boc-L-Lys and $N_{\varepsilon}$-L-Lys NDIs displayed minor stabilization effects $\left(\Delta T_{\mathrm{m}}<2{ }^{\circ} \mathrm{C}\right)$, as depicted in Table $6 \mathrm{a}, \mathrm{b}$. This indicates that such types of ligands have selectivity for certain G4 DNA over dsDNA. The VT CD single-wavelength spectra of dsDNA by itself as well as dsDNA-NDI assemblies and their corresponding Boltzmann fitting curves are given in Supplementary Material, Figure S18. 
Table 6. The $T_{\mathrm{m}}$ values of dsDNA only compared to the $T_{\mathrm{m}}$ of (a) dsDNA-Boc-protected-NDIs and (b) dsDNA-deprotected-NDIs as determined from VT CD studies.

\begin{tabular}{cc|cc}
\hline (a) & & (b) & \\
\hline Sequence/Assembly & $\boldsymbol{T}_{\mathbf{m}}\left({ }^{\circ} \mathbf{C}\right)$ & Sequence/Assembly & $\boldsymbol{T}_{\mathbf{m}}\left({ }^{\circ} \mathbf{C}\right)$ \\
\hline dsDNA only & $55.1 \pm 0.8^{\mathrm{a}} / 55.6 \pm 0.3^{\mathrm{b}}$ & dsDNA only & $55.1 \pm 0.8^{\mathrm{a}} / 55.6 \pm 0.3^{\mathrm{b}}$ \\
$N_{\varepsilon}$-Boc-L-Lys NDI & $52.6 \pm 0.8$ & $N_{\varepsilon}$-L-Lys NDI & $56.9 \pm 1.5$ \\
$N_{\varepsilon}$-Boc-D-Lys NDI & $53.8 \pm 0.2$ & $N_{\varepsilon}$-D-Lys NDI & $53.7 \pm 0.3$ \\
$N_{\alpha}$-Boc-L-Lys NDI & $57.0 \pm 1.2$ & $N_{\alpha}$-L-Lys NDI & $55.8 \pm 0.7$ \\
$N_{\alpha}$-Boc-D-Lys NDI & $56.1 \pm 0.6$ & $N_{\alpha}$-D-Lys NDI & $50.7 \pm 0.3$ \\
\hline
\end{tabular}

${ }^{a}$ This value was used for calculating the $T_{\mathrm{m}}$ for all dsDNA-L-NDIs assemblies; ${ }^{\mathrm{b}}$ This value was used for calculating the $T_{\mathrm{m}}$ for all dsDNA-D-NDIs assemblies.

\section{Materials and Methods}

The oligonucleotides used in this study were purchased from Invitrogen ${ }^{\circledR}$, having the following sequences (from $5^{\prime}$ to $3^{\prime}$ ): c-KIT1: GGG AGG GCG CTG GGA GGA GGG; c-KIT2: GGG CGG GCG CGA GGG AGG GG; k-RAS: AGG GCG GTG TGG GAA GAG GGA AGA GGG GGA GG; h-TELO: AGG GTT AGG GTT AGG GTT AGG GT; BCL-2: GGG CGC GGG AGG AAG GGG GCG GG; dsDNA: TAT AGC TAT A Heg TA TAG CTA. The sequences were used as received without further purification.

The oligonucleotide solutions were annealed in pH 7.4 PBS (phosphate-buffered saline) that contained $\mathrm{KH}_{2} \mathrm{PO}_{4} / \mathrm{K}_{2} \mathrm{HPO}_{4}(10 \mathrm{mM})$ and potassium fluoride $(\mathrm{KF}, 100 \mathrm{mM})$. The oligonucleotide solutions were placed in a dry-block heater at $95{ }^{\circ} \mathrm{C}$ for exactly $5 \mathrm{~min}$, before being allowed to cool to room temperature and stored at $4{ }^{\circ} \mathrm{C}$ for at least $24 \mathrm{~h}$ prior to use. The samples were annealed to $10 \mu \mathrm{M}$, then diluted to desired concentration (3-10 $\mu \mathrm{M}$ range) and used without further purification. The exact concentration of each oligonucleotide after annealing (and the corresponding diluted batches) was determined by measuring the absorbance for the peak corresponding to $\lambda_{\max }$. The extinction coefficients were provided by the manufacturer. The following values were used (given in $\mathrm{L} \mathrm{mol}^{-1} \mathrm{~cm}^{-1}$ ): c-KIT2: 199,100; c-KIT1: 213,000; k-RAS: 341,000; BCL-2: 221,000; h-TELO: 237,000; dsDNA: 6600.

The concentration of the DNA sequence used in each experiment is given in the Supplementary Materials.

Ultrapure water from a Milli-Q ${ }^{\circledR}$ water system was used in all CD experiments. All other reagents and solvents were supplied by either Sigma-Aldrich (Gillingham, UK), VWR (Lutterworth, UK) or TCI (Oxford, UK) and used as received. Microwave-assisted reactions were conducted in a CEM ${ }^{\circledR}$ microwave reactor. Samples for NMR analyses were prepared using dimethylsulfoxide (DMSO- $d_{6}$ ). The ${ }^{1} \mathrm{H}$ and ${ }^{13} \mathrm{C}$ NMR spectra were acquired at 500 and $126 \mathrm{MHz}$, respectively, using an Agilent ProPulse spectrometer (Santa Clara, CA, USA). The data was recorded at $298 \mathrm{~K}$, and the spectra were referenced to the residual solvent peak. Coupling constants are reported in Hertz $(\mathrm{Hz})$, and signal multiplicity is denoted as singlet (s), broad singlet (br s), doublet (d), doublet of doublets (dd), triplet (t), quartet (q), multiplet $(\mathrm{m})$. Chemical shifts are reported in parts per million $(\mathrm{ppm})$. The nanospray ionization (NSI) spectra (negative or positive ion, as specified) were recorded on an LTQ Orbitrap XL hybrid FTMS instrument. The synthetic route for all NDIs followed a previously reported procedure [35].

The synthesis and characterization data for L-NDIs is reported in our previous work [35]. ${ }^{1} \mathrm{H}$ and ${ }^{13} \mathrm{C}$ NMR and MS spectra of both D- and L-NDIs are provided for completeness in Supplementary Material Section 1 (pages S2-S14).

\subsection{Synthesis of $N_{\alpha}-B o c-\mathrm{D}-L y s$ and $N_{\varepsilon}$-Boc-D-Lys NDIs}

An 8-mL microwave tube was charged with 1,4,5,8-naphthalenetetracarboxylic dianhydride (NDA) and dissolved in dry DMF ( $5 \mathrm{~mL})$. The corresponding amino acid was added to the formed suspension along with dry $\mathrm{Et}_{3} \mathrm{~N}(0.2 \mathrm{~mL})$. The mixture was sonicated until it became a homogeneous solution. The reaction mixture was heated under microwave irradiation for $5 \mathrm{~min}$ at $140{ }^{\circ} \mathrm{C}$. The solvent was removed under reduced pressure to yield a brown residue, which was further suspended in minimum amount of acetone. The suspension was added dropwise to a vigorously stirred solution of 
$1 \mathrm{M} \mathrm{HCl}_{\text {(aq.) }}(200 \mathrm{~mL})$. The resulting precipitate was filtered off and dried in vacuum to yield a light brown colored solid.

$N_{\alpha}$-Boc-D-Lys NDI: The reaction was performed on 1 equivalent of NDA (200 $\left.\mathrm{mg}, 0.746 \mathrm{mmol}\right)$ and 2.1 equivalents of $N_{\alpha}$-Boc-D-lysine ( $386 \mathrm{mg}, 1.567 \mathrm{mmol}$ ) by using the general procedure. Yield: $524 \mathrm{mg}, 92 \%$; ${ }^{1} \mathrm{H}$ NMR $\left(500 \mathrm{MHz}, \mathrm{DMSO}-d_{6}\right): \delta 12.40(\mathrm{br} \mathrm{s}, 2 \mathrm{H}), 8.67(\mathrm{~s}, 4 \mathrm{H}), 7.03\left(\mathrm{~d}, J_{(\mathrm{H}, \mathrm{H})}=8.1 \mathrm{~Hz}\right.$, $2 \mathrm{H}), 4.05\left(\mathrm{t}, J_{(\mathrm{H}, \mathrm{H})}=7.4 \mathrm{~Hz}, 4 \mathrm{H}\right), 3.88-3.79(\mathrm{~m}, 2 \mathrm{H}), 1.76-1.50(\mathrm{~m}, 8 \mathrm{H}), 1.36-1.30(\mathrm{~m}, 22 \mathrm{H}) ;{ }^{13} \mathrm{C} \mathrm{NMR}$ (126 MHz, DMSO- $d_{6}$ ): $\delta$ 174.6, 163.0, 156.0, 130.8, 126.6, 126.5, 78.3, 53.7, 36.2, 31.9, 28.6, 27.5, 23.6; FTMS-NSI: $m / z$ calcd for $\mathrm{C}_{36} \mathrm{H}_{44} \mathrm{~N}_{4} \mathrm{O}_{12}: 723.2883\left[\mathrm{C}_{36} \mathrm{H}_{44} \mathrm{~N}_{4} \mathrm{O}_{12}-\mathrm{H}\right]^{-}$, found: 723.2873 .

$N_{\varepsilon}$-Boc-D-Lys NDI: The reaction was performed on 1 equivalent of NDA ( $\left.200 \mathrm{mg}, 0.746 \mathrm{mmol}\right)$ and 2.1 equivalents of $N_{\varepsilon}$-Boc-D-lysine $(386 \mathrm{mg}, 1.567 \mathrm{mmol})$ by using the general procedure. Yield: $554 \mathrm{mg}, 98 \%$; ${ }^{1} \mathrm{H}$ NMR (500 MHz, DMSO- $\left.d_{6}\right): \delta 12.85(\mathrm{br} \mathrm{s}, 2 \mathrm{H}), 8.75(\mathrm{~s}, 4 \mathrm{H}), 6.67\left(\mathrm{t}, J_{(\mathrm{H}, \mathrm{H})}=6.0 \mathrm{~Hz}\right.$, $2 \mathrm{H}), 5.53\left(\mathrm{dd}, J_{(\mathrm{H}, \mathrm{H})}=9.4,5.0 \mathrm{~Hz}, 2 \mathrm{H}\right), 2.85-2.79(\mathrm{~m}, 4 \mathrm{H}), 2.27-2.17(\mathrm{~m}, 4 \mathrm{H}), 2.10-2.01(\mathrm{~m}, 4 \mathrm{H}), 1.21(\mathrm{~s}$, 22H); ${ }^{13}$ C NMR (126 MHz, DMSO- $d_{6}$ ): $\delta$ 171.1, 162.8, 155.9, 131.7, 126.8, 126.4, 77.6, 54.0, 36.3, 31.2, 29.8, 28.6, 23.7; FTMS-NSI: $m / z$ calcd for $\mathrm{C}_{36} \mathrm{H}_{44} \mathrm{~N}_{4} \mathrm{O}_{12}: 723.2883\left[\mathrm{C}_{36} \mathrm{H}_{44} \mathrm{~N}_{4} \mathrm{O}_{12}-\mathrm{H}\right]^{-}$, found: 723.2874 .

\subsection{Synthesis of $N_{\alpha}$-D-Lys and $N_{\varepsilon}$-D-Lys NDIs}

The deprotected derivatives ( $N_{\alpha}$-D-Lys and $N_{\varepsilon}$-D-Lys NDIs) were obtained from $N_{\alpha}$-Boc-D-Lys and $N_{\mathcal{E}}$-Boc-D-Lys NDIs via the following general procedure: a $25-\mathrm{mL}$ round-bottomed flask equipped with a stirrer bar was charged with starting material (NDI) suspended in $\mathrm{CH}_{2} \mathrm{Cl}_{2}(5 \mathrm{~mL})$ and trifluoroacetic acid $(5 \mathrm{~mL})$ was added to the suspension. The reaction mixture was stirred at room temperature for $3 \mathrm{~h}$. The solvents were removed under reduced pressure, and the residue was subsequently washed with diethyl ether $(2 \times 30 \mathrm{~mL})$, filtered, and vacuum dried to yield a light brown solid in both cases.

$N_{\alpha}$-D-Lys NDI: The aforementioned general procedure was followed using $N_{\alpha}$-Boc-D-Lys NDI (394 mg). Yield: $331 \mathrm{mg}, 85 \%$; ${ }^{1}$ H NMR (500 MHz, DMSO- $d_{6}$ ): $\delta 13.05$ (br s, 2H), 8.66 (s, 4H), 8.16 (br $\mathrm{s}, 6 \mathrm{H}), 4.04\left(\mathrm{t}, J_{(\mathrm{H}, \mathrm{H})}=7.6 \mathrm{~Hz}, 4 \mathrm{H}\right), 3.92-3.84(\mathrm{~m}, 2 \mathrm{H}), 1.88-1.72(\mathrm{~m}, 8 \mathrm{H}), 1.72-1.60(\mathrm{~m}, 4 \mathrm{H}) ;{ }^{13} \mathrm{C} \mathrm{NMR}$ (126 MHz, DMSO- $d_{6}$ ): $\delta$ 171.5, 163.1, 158.9, 158.4, 130.9, 126.8, 126.6, 52.3, 50.2, 30.2, 27.4, 24.2, 22.4; FTMS-NSI: $m / z$ calcd for $\mathrm{C}_{26} \mathrm{H}_{29} \mathrm{~N}_{4} \mathrm{O}_{8}: 525.1993\left[\mathrm{C}_{26} \mathrm{H}_{29} \mathrm{~N}_{4} \mathrm{O}_{8}-\mathrm{H}\right]^{+}$, found: 525.1980 .

$N_{\varepsilon}$-D-Lys NDI: The aforementioned general procedure was following using $N_{\varepsilon}$-Boc-D-Lys NDI (275 mg). Yield: $176 \mathrm{mg}, 62 \%$; ${ }^{1} \mathrm{H}$ NMR (500 MHz, DMSO- $\boldsymbol{d}_{6}$ ): $\delta 12.39$ (br s, 2H), $8.74(\mathrm{~s}, 4 \mathrm{H}), 7.59$ (br $\mathrm{s}, 6 \mathrm{H}), 5.53\left(\mathrm{dd}, J_{(\mathrm{H}, \mathrm{H})}=8.9,5.3 \mathrm{~Hz}, 2 \mathrm{H}\right), 3.37\left(\mathrm{t}, J_{(\mathrm{H}, \mathrm{H})}=7.0 \mathrm{~Hz}, 4 \mathrm{H}\right), 2.31-2.23(\mathrm{~m}, 4 \mathrm{H}), 2.08-2.00(\mathrm{~m}$, $4 \mathrm{H}), 1.08\left(\mathrm{q}, J_{(\mathrm{H}, \mathrm{H})}=7.0 \mathrm{~Hz}, 4 \mathrm{H}\right) ;{ }^{13} \mathrm{C}$ NMR (126 MHz, DMSO- $\left.d_{6}\right): \delta 171.1,162.9,131.7,126.9,126.5$, $53.8,39.1,36.2,28.5,27.3,23.4$. The MS data could not be acquired because of the aggregation issue.

\subsection{Variable-Temperature CD Studies}

$\mathrm{CD}$ and UV-vis experiments were performed on an Applied Photophysics Chirascan Circular Dichroism Spectrophotometer (Leatherhead, UK) equipped with a Peltier temperature controller. The following parameters were used for full spectra measurements: wavelength scanning range 220-420 nm; temperature $5.0^{\circ} \mathrm{C}$; scanning increments $1 \mathrm{~nm}$; monochromator bandwidth $2.5 \mathrm{~nm}$; sampling time-per-point $0.5 \mathrm{~s}$; pathlength cuvette $1 \mathrm{~mm}$.

In all variable-temperature (VT) studies, the ligand (10 equivalents) was added to the DNA sequence solution previously annealed. Any samples with a maximum ellipticity $<4.0$ mdeg were transferred to a quartz cuvette with a longer pathlength $(2,5$ and $10 \mathrm{~mm}$ cuvettes were used). For VT experiments, a single-wavelength spectrum was recorded using the wavelength with the maximum ellipticity $\left(\lambda_{\max }\right)$ with the following parameters: temperature range $5-95{ }^{\circ} \mathrm{C}$ with $1{ }^{\circ} \mathrm{C}$ increments; temperature slope $1^{\circ} \mathrm{C} \mathrm{min}{ }^{-1}$; temperature equilibration time $45 \mathrm{~s}$; monochromator bandwidth $2.5 \mathrm{~nm}$; sampling time-per-point $2.0 \mathrm{~s}$. The VT CD data was processed using QtiPlot ${ }^{\circledR}$ (version 0.9.8.9, București, Romania), and fitted to the Boltzmann equation (the spectra are given in the Supplementary Materials). 


\section{Conclusions}

We have synthesized the D-enantiomers of L-Lys NDIs (with chiral center proximal and distal from the polyaromatic unit) and screened them against G4-forming sequences in telomeres (h-TELO) and the oncogene promoters c-KIT1, c-KIT2, k-RAS and BCL-2. To the best of our knowledge, this is the first study to explore the effect of point chirality in metal-free ligands and chiral recognition toward stabilizing G4 DNA sequences. The heat map table in Figure 8 summarizes the potential of L-NDIs (a) vs. D-NDIs (b) as G4 and dsDNA binders.

R elative stabilisation by enan tiom ers $\Delta\left(\Delta T_{m} \mathbf{L}-\Delta T_{m} \mathbf{D}\right)$

\begin{tabular}{|c|c|c|c|c|c|c|}
\hline & $\mathrm{c}-\mathrm{K}$ IT 2 & c-K IT 1 & $\mathrm{k} R \mathrm{RAS}$ & BC L -2 & h-TELO & $\mathrm{d} s \mathrm{~N}$ A \\
\hline$N_{\alpha}$-Boc-Lys NDI & 8.8 & 0.0 & 3.4 & 3.0 & -2.0 & 1.4 \\
\hline$N_{\alpha}$-Lys NDI & 8.2 & 6.9 & -4.4 & -3.0 & -0.5 & 5.6 \\
\hline$N_{\varepsilon}-$ Boc-Lys NDI & 16.2 & -3.0 & 3.7 & -3.2 & 1.5 & -0.7 \\
\hline$N_{\varepsilon}$-Lys NDI & -1.0 & -1.2 & 5.3 & -0.7 & 1.1 & 3.7 \\
\hline
\end{tabular}

Figure 8. Heat map of the differential stabilization of the studied DNA sequences by the NDI enantiomers. The values represent the difference between the $\Delta T_{\mathrm{m}}$ for the $\mathrm{L}$-enantiomer and the $\Delta T_{\mathrm{m}}$ for the D-enantiomers with each oligonucleotide. Different concentrations were used for $\mathrm{N}_{\varepsilon}$-Lys NDIs (150 $\mu \mathrm{M}$ for L-NDI and $75 \mu \mathrm{M}$ for D-NDI); DNA concentration was kept similar for all measurements. All the values are in ${ }^{\circ} \mathrm{C}$ as determined from VT CD studies.

Enantioselectivity was observed for certain ligand/quadruplex pairs adopting parallel or hybrid conformations. The biggest stabilization difference between the enantiomers was observed for $N_{\varepsilon}$-Boc-Lys NDI interacting with c-KIT2, where the L-enantiomer stabilizes the quadruplex sequence 16 ${ }^{\circ} \mathrm{C}$ more than the D-enantiomer; the latter has a mild destabilizing effect on the c-KIT2 oligonucleotide (Table 1). The protected and deprotected $N_{\alpha}$-Lys NDI enantiomers showed differential stabilization toward this quadruplex in favor of the L-enantiomer. All of the NDI ligands displayed enantiomeric differentiation in the interaction with c-KIT1, k-RAS and BCL-2 with the exception of $N_{\alpha}$-Boc-Lys NDI and c-KIT1, and $N_{\varepsilon}$-Lys NDI with both c-KIT1 and BCL-2. h-TELO does not have a strong interaction with any of the NDI ligands studied.

The enantioselectivity observed cannot be explained by the aromatic $\pi-\pi$ stacking of the NDI core on the terminal G-tetrads, thus implying that the sidechain interaction with the loops is the cause of this selectivity. This study paves the way toward further exploration of chiral ligands for G4 DNA with the hope of developing a new generation of G-quadruplex sequence selective anticancer drugs.

Supplementary Materials: The Supplementary Materials are available online. CD analysis of all DNA sequences with and without the ligand before and during VT CD studies are given in Figures $\mathrm{S} 1-\mathrm{S} 11 ;{ }^{1} \mathrm{H},{ }^{13} \mathrm{C}$ NMR, and MS spectra of both L- and D-NDIs are supplied in Section 1 (pages S2-S14). VT CD melting curves and the corresponding Boltzmann fittings are provided in Section 3, Figures S12-S18. Size exclusion chromatography (SEC) analysis of the all the DNA sequences is presented in Figure S19.

Author Contributions: Conceptualization: G.D.P. and D.M.R.; writing_original draft preparation, S.W.O.H.; writing-review and editing: D.M.R. and G.D.P.; analytical data acquisition and processing: S.W.O.H., D.M.R., I.R.O., A.M., F.M.B.; synthesis: I.R.O., A.M.; supervision, G.D.P.; project administration, G.D.P.

Funding: This research was funded by the University of Bath.

Acknowledgments: We thank the University of Bath for funding and the EPSRC UK National Mass Spectrometry Facility at Swansea University for high resolution mass spectrometry analyses.

Conflicts of Interest: The authors declare no conflict of interest. The funders had no role in the design of the study; in the collection, analyses, or interpretation of data; in the writing of the manuscript, or in the decision to publish the results. 


\section{References}

1. Koirala, D.; Dhakal, S.; Ashbridge, B.; Sannohe, Y.; Rodriguez, R.; Sugiyama, H.; Balasubramanian, S.; Mao, H. A single-molecule platform for investigation of interactions between G-quadruplexes and small-molecule ligands. Nat. Chem. 2011, 3, 782-787. [CrossRef] [PubMed]

2. Mao, S.-Q.; Ghanbarian, A.T.; Spiegel, J.; Martínez Cuesta, S.; Beraldi, D.; Di Antonio, M.; Marsico, G.; Hänsel-Hertsch, R.; Tannahill, D.; Balasubramanian, S. DNA G-quadruplex structures mold the DNA methylome. Nat. Struct. Mol. Biol. 2018, 25, 951-957. [CrossRef] [PubMed]

3. Bončina, M.; Podlipnik, Č.; Piantanida, I.; Eilmes, J.; Teulade-Fichou, M.-P.; Vesnaver, G.; Lah, J. Thermodynamic fingerprints of ligand binding to human telomeric G-quadruplexes. Nucleic Acids Res. 2015, 43, 10376-10386. [CrossRef] [PubMed]

4. Rhodes, D.; Lipps, H.J. G-quadruplexes and their regulatory roles in biology. Nucleic Acids Res. 2015, 43, 8627-8637. [CrossRef]

5. Bochman, M.L.; Paeschke, K.; Zakian, V.A. DNA secondary structures: Stability and function of G-quadruplex structures. Nat. Rev. Genet. 2012, 13, 770-780. [CrossRef] [PubMed]

6. Smargiasso, N.; Rosu, F.; Hsia, W.; Colson, P.; Baker, E.S.; Bowers, M.T.; De Pauw, E.; Gabelica, V. G-Quadruplex DNA Assemblies: Loop Length, Cation Identity, and Multimer Formation. J. Am. Chem. Soc. 2008, 130, 10208-10216. [CrossRef]

7. Rankin, S.; Reszka, A.P.; Huppert, J.; Zloh, M.; Parkinson, G.N.; Todd, A.K.; Ladame, S.; Balasubramanian, S.; Neidle, S. Putative DNA Quadruplex Formation within the Human c-kit Oncogene. J. Am. Chem. Soc. 2005, 127, 10584-10589. [CrossRef] [PubMed]

8. Collie, G.W.; Promontorio, R.; Hampel, S.M.; Micco, M.; Neidle, S.; Parkinson, G.N. Structural Basis for Telomeric G-Quadruplex Targeting by Naphthalene Diimide Ligands. J. Am. Chem. Soc. 2012, 134, $2723-2731$. [CrossRef]

9. Marchetti, C.; Minarini, A.; Tumiatti, V.; Moraca, F.; Parrotta, L.; Alcaro, S.; Rigo, R.; Sissi, C.; Gunaratnam, M.; Ohnmacht, S.A.; et al. Macrocyclic naphthalene diimides as G-quadruplex binders. Bioorgan. Med. Chem. 2015, 23, 3819-3830. [CrossRef]

10. Hampel, S.M.; Pepe, A.; Greulich-Bode, K.M.; Malhotra, S.V.; Reszka, A.P.; Veith, S.; Boukamp, P.; Neidle, S. Mechanism of the Antiproliferative Activity of Some Naphthalene Diimide G-Quadruplex Ligands. Mol. Pharmacol. 2013, 83, 470-480. [CrossRef]

11. Siddiqui-Jain, A.; Grand, C.L.; Bearss, D.J.; Hurley, L.H. Direct evidence for a G-quadruplex in a promoter region and its targeting with a small molecule to repress c-MYC transcription. Proc. Natl. Acad. Sci. USA 2002, 99, 11593-11598. [CrossRef]

12. Deng, N.; Wickstrom, L.; Cieplak, P.; Lin, C.; Yang, D. Resolving the Ligand-Binding Specificity in c-MYC G-Quadruplex DNA: Absolute Binding Free Energy Calculations and SPR Experiment. J. Physic. Chem. B 2017, 121, 10484-10497. [CrossRef]

13. Dash, J.; Shirude, P.S.; Balasubramanian, S. G-quadruplex recognition by bis-indole carboxamides. Chem. Commun. 2008, 3055-3057. [CrossRef]

14. Chauhan, A.; Paladhi, S.; Debnath, M.; Dash, J. Selective recognition of c-MYC G-quadruplex DNA using prolinamide derivatives. Org. Biomol. Chem. 2016, 14, 5761-5767. [CrossRef]

15. Głuszyńska, A.; Juskowiak, B.; Kuta-Siejkowska, M.; Hoffmann, M.; Haider, S. Carbazole Derivatives' Binding to c-KIT G-Quadruplex DNA. Molecules 2018, 23, 1134. [CrossRef]

16. Maiti, S.; Saha, P.; Das, T.; Bessi, I.; Schwalbe, H.; Dash, J. Human Telomeric G-Quadruplex Selective Fluoro-Isoquinolines Induce Apoptosis in Cancer Cells. Bioconjugate Chem. 2018, 29, 1141-1154. [CrossRef]

17. Franceschin, M.; Cianni, L.; Pitorri, M.; Micheli, E.; Cacchione, S.; Frezza, C.; Serafini, M.; Hu, M.-H.; Su, H.; Huang, Z.; et al. Natural Aromatic Compounds as Scaffolds to Develop Selective G-Quadruplex Ligands: From Previously Reported Berberine Derivatives to New Palmatine Analogues. Molecules 2018, $23,1423$. [CrossRef]

18. Bugaut, A.; Jantos, K.; Wietor, J.-L.; Rodriguez, R.; Sanders, J.K.M.; Balasubramanian, S. Exploring the Differential Recognition of DNA G-Quadruplex Targets by Small Molecules Using Dynamic Combinatorial Chemistry. Angew. Chem. Int. Ed. 2008, 47, 2677-2680. [CrossRef]

19. Müller, S.; Kumari, S.; Rodriguez, R.; Balasubramanian, S. Small-molecule-mediated G-quadruplex isolation from human cells. Nat. Chem. 2010, 2, 1095-1098. [CrossRef] 
20. Müller, S.; Pantoş, G.D.; Rodriguez, R.; Balasubramanian, S. Controlled-folding of a small molecule modulates DNA G-quadruplex recognition. Chem. Commun. 2009, 80-82. [CrossRef]

21. Bejugam, M.; Sewitz, S.; Shirude, P.S.; Rodriguez, R.; Shahid, R.; Balasubramanian, S. Trisubstituted Isoalloxazines as a New Class of G-Quadruplex Binding Ligands: Small Molecule Regulation of c-kit Oncogene Expression. J. Am. Chem. Soc. 2007, 129, 12926-12927. [CrossRef]

22. Jantos, K.; Rodriguez, R.; Ladame, S.; Shirude, P.S.; Balasubramanian, S. Oxazole-Based Peptide Macrocycles: A New Class of G-Quadruplex Binding Ligands. J. Am. Chem. Soc. 2006, 128, 13662-13663. [CrossRef]

23. Hahn, L.; Buurma, N.J.; Gade, L.H. A Water-Soluble Tetraazaperopyrene Dye as Strong G-Quadruplex DNA Binder. Chem. Eur. J. 2016, 22, 6314-6322. [CrossRef]

24. Gonçalves, D.P.N.; Rodriguez, R.; Balasubramanian, S.; Sanders, J.K.M. Tetramethylpyrid iniumporphyrazines-A new class of G-quadruplex inducing and stabilising ligands. Chem. Commun. 2006, 4685-4687. [CrossRef]

25. Rodriguez, R.; Pantoş, G.D.; Gonçalves, D.P.N.; Sanders, J.K.M.; Balasubramanian, S. Ligand-Driven G-Quadruplex Conformational Switching by Using an Unusual Mode of Interaction. Angew. Chem. Int. Ed. 2007, 46, 5405-5407. [CrossRef]

26. Dash, J.; Waller, Z.A.E.; Pantoş, G.D.; Balasubramanian, S. Synthesis and Binding Studies of Novel Diethynyl-Pyridine Amides with Genomic Promoter DNA G-Quadruplexes. Chem. Eur. J. 2011, 17, 4571-4581. [CrossRef]

27. Bandeira, S.; Gonzalez-Garcia, J.; Pensa, E.; Albrecht, T.; Vilar, R. A Redox-Activated G-Quadruplex DNA Binder Based on a Platinum(IV)-Salphen Complex. Angew. Chem. Int. Ed. 2018, 57, 310-313. [CrossRef]

28. Petenzi, M.; Verga, D.; Largy, E.; Hamon, F.; Doria, F.; Teulade-Fichou, M.-P.; Guédin, A.; Mergny, J.-L.; Mella, M.; Freccero, M. Cationic Pentaheteroaryls as Selective G-Quadruplex Ligands by Solvent-Free Microwave-Assisted Synthesis. Chem. Eur. J. 2012, 18, 14487-14496. [CrossRef]

29. Hamon, F.; Largy, E.; Guédin-Beaurepaire, A.; Rouchon-Dagois, M.; Sidibe, A.; Monchaud, D.; Mergny, J.-L.; Riou, J.-F.; Nguyen, C.-H.; Teulade-Fichou, M.-P. An Acyclic Oligoheteroaryle That Discriminates Strongly between Diverse G-Quadruplex Topologies. Angew. Chem. Int. Ed. 2011, 50, 8745-8749. [CrossRef]

30. Rizeq, N.; Georgiades, S. Investigation of 'Head-to-Tail'-Connected Oligoaryl N,O-Ligands as Recognition Motifs for Cancer-Relevant G-Quadruplexes. Molecules 2017, 22, 2160. [CrossRef]

31. Medeiros-Silva, J.; Guédin, A.; Salgado, G.F.; Mergny, J.-L.; Queiroz, J.A.; Cabrita, E.J.; Cruz, C. Phenanthroline-bis-oxazole ligands for binding and stabilization of G-quadruplexes. BBA—Gen. Subj. 2017, 1861, 1281-1292. [CrossRef] [PubMed]

32. Drygin, D.; Siddiqui-Jain, A.; O’Brien, S.; Schwaebe, M.; Lin, A.; Bliesath, J.; Ho, C.B.; Proffitt, C.; Trent, K.; Whitten, J.P.; et al. Anticancer Activity of CX-3543: A Direct Inhibitor of rRNA Biogenesis. Cancer Res. 2009, 69, 7653-7661. [CrossRef] [PubMed]

33. Hampel, S.M.; Sidibe, A.; Gunaratnam, M.; Riou, J.-F.; Neidle, S. Tetrasubstituted naphthalene diimide ligands with selectivity for telomeric G-quadruplexes and cancer cells. Bioorg an. Med. Chem. Lett. 2010, 20, 6459-6463. [CrossRef] [PubMed]

34. Mpima, S.; Ohnmacht, S.A.; Barletta, M.; Husby, J.; Pett, L.C.; Gunaratnam, M.; Hilton, S.T.; Neidle, S. The influence of positional isomerism on G-quadruplex binding and anti-proliferative activity of tetra-substituted naphthalene diimide compounds. Bioorgan. Med. Chem. 2013, 21, 6162-6170. [CrossRef] [PubMed]

35. Răsădean, D.M.; Sheng, B.; Dash, J.; Pantoş, G.D. Amino-Acid-Derived Naphthalenediimides as Versatile G-Quadruplex Binders. Chem. Eur. J. 2017, 23, 8491-8499. [CrossRef] [PubMed]

36. Marchetti, C.; Zyner, K.G.; Ohnmacht, S.A.; Robson, M.; Haider, S.M.; Morton, J.P.; Marsico, G.; Vo, T.; Laughlin-Toth, S.; Ahmed, A.A.; et al. Targeting Multiple Effector Pathways in Pancreatic Ductal Adenocarcinoma with a G-Quadruplex-Binding Small Molecule. J. Med. Chem. 2018, 61, 2500-2517. [CrossRef]

37. Nadai, M.; Doria, F.; Scalabrin, M.; Pirota, V.; Grande, V.; Bergamaschi, G.; Amendola, V.; Winnerdy, F.R.; Phan, A.T.; Richter, S.N.; et al. A Catalytic and Selective Scissoring Molecular Tool for Quadruplex Nucleic Acids. J. Am. Chem. Soc. 2018, 140, 14528-14532. [CrossRef]

38. Nadai, M.; Doria, F.; Di Antonio, M.; Sattin, G.; Germani, L.; Percivalle, C.; Palumbo, M.; Richter, S.N.; Freccero, M. Naphthalene diimide scaffolds with dual reversible and covalent interaction properties towards G-quadruplex. Biochimie 2011, 93, 1328-1340. [CrossRef] 
39. Ohnmacht, S.A.; Marchetti, C.; Gunaratnam, M.; Besser, R.J.; Haider, S.M.; Di Vita, G.; Lowe, H.L.; Mellinas-Gomez, M.; Diocou, S.; Robson, M.; et al. A G-quadruplex-binding compound showing anti-tumour activity in an in vivo model for pancreatic cancer. Sci. Rep. 2015, 5, 11385. [CrossRef]

40. Islam, M.; Fujii, S.; Sato, S.; Okauchi, T.; Takenaka, S. A Selective G-Quadruplex DNA-Stabilizing Ligand Based on a Cyclic Naphthalene Diimide Derivative. Molecules 2015, 20, 10963-10979. [CrossRef]

41. Prato, G.; Silvent, S.; Saka, S.; Lamberto, M.; Kosenkov, D. Thermodynamics of Binding of Di- and Tetrasubstituted Naphthalene Diimide Ligands to DNA G-Quadruplex. J. Phys. Chem. B 2015, 119, 3335-3347. [CrossRef]

42. Nguyen, L.A.; He, H.; Pham-Huy, C. Chiral Drugs: An Overview. IJBS 2006, 2, 85.

43. Mc.Conathy, J.; Owens, M.J. Stereochemistry in Drug Action. Prim. Care Companion J. Clinic. Psychiatry 2003, 5, 70. [CrossRef]

44. Roe, S.; Ritson, D.J.; Garner, T.; Searle, M.; Moses, J.E. Tuneable DNA-based asymmetric catalysis using a G-quadruplex supramolecular assembly. Chem. Commun. 2010, 46, 4309. [CrossRef]

45. Qin, H.; Zhao, C.; Sun, Y.; Ren, J.; Qu, X. Metallo-supramolecular Complexes Enantioselectively Eradicate Cancer Stem Cells in Vivo. J. Am. Chem. Soc. 2017, 139, 16201-16209. [CrossRef]

46. Yu, H.; Wang, X.; Fu, M.; Ren, J.; Qu, X. Chiral metallo-supramolecular complexes selectively recognize human telomeric G-quadruplex DNA. Nucleic Acids Res. 2008, 36, 5695-5703. [CrossRef]

47. Engelhard, D.M.; Stratmann, L.M.; Clever, G.H. Structure-Property Relationships in Cu II -Binding Tetramolecular G-Quadruplex DNA. Chem. Eur. J. 2018, 24, 2117-2125. [CrossRef]

48. Engelhard, D.M.; Nowack, J.; Clever, G.H. Copper-Induced Topology Switching and Thrombin Inhibition with Telomeric DNA G-Quadruplexes. Angew. Chem. Int. Ed. 2017, 56, 11640-11644. [CrossRef]

49. Qin, Q.-P.; Qin, J.-L.; Chen, M.; Li, Y.-L.; Meng, T.; Zhou, J.; Liang, H.; Chen, Z.-F. Chiral platinum (II)-4-(2,3-dihydroxypropyl)- formamide oxo-aporphine (FOA) complexes promote tumor cells apoptosis by directly targeting G-quadruplex DNA in vitro and in vivo. Oncotarget 2017, 8. [CrossRef]

50. Wang, J.; Chen, Y.; Ren, J.; Zhao, C.; Qu, X. G-Quadruplex binding enantiomers show chiral selective interactions with human telomere. Nucleic Acids Res. 2014, 42, 3792-3802. [CrossRef]

51. Huang, X.-X.; Zhu, L.-N.; Wu, B.; Huo, Y.-F.; Duan, N.-N.; Kong, D.-M. Two cationic porphyrin isomers showing different multimeric G-quadruplex recognition specificity against monomeric G-quadruplexes. Nucleic Acids Res. 2014, 42, 8719-8731. [CrossRef] [PubMed]

52. Ng, C.H.; Chan, C.W.; Lai, J.W.; Ooi, I.H.; Chong, K.V.; Maah, M.J.; Seng, H.L. Enantiomeric pair of copper(II) polypyridyl-alanine complexes: Effect of chirality on their interaction with biomolecules. J. Inorgan. Biochem. 2016, 160, 1-11. [CrossRef] [PubMed]

53. Wilson, T.; Costa, P.J.; Félix, V.; Williamson, M.P.; Thomas, J.A. Structural Studies on Dinuclear Ruthenium(II) Complexes That Bind Diastereoselectively to an Antiparallel Folded Human Telomere Sequence. J. Med. Chem. 2013, 56, 8674-8683. [CrossRef] [PubMed]

54. Yu, Q.; Liu, Y.; Wang, C.; Sun, D.; Yang, X.; Liu, Y.; Liu, J. Chiral Ruthenium(II) Polypyridyl Complexes: Stabilization of G-Quadruplex DNA, Inhibition of Telomerase Activity and Cellular Uptake. PLoS ONE 2012, 7, e50902. [CrossRef] [PubMed]

55. Zhang, Z.; Mei, W.; Wu, X.; Wang, X.; Wang, B.; Chen, S. Synthesis and characterization of chiral ruthenium(II) complexes $\Lambda / \Delta-\left[\mathrm{Ru}(\mathrm{bpy})_{2}\left(\mathrm{H}_{2} \mathrm{iip}\right)\right]\left(\mathrm{ClO}_{4}\right)_{2}$ as stabilizers of $c-m y c$ G-quadruplex DNA. J. Coord. Chem. 2015, 68, 1465-1475. [CrossRef]

56. Zhao, A.; Howson, S.E.; Zhao, C.; Ren, J.; Scott, P.; Wang, C.; Qu, X. Chiral metallohelices enantioselectively target hybrid human telomeric G-quadruplex DNA. Nucleic Acids Res. 2017, 45, 5026-5035. [CrossRef] [PubMed]

57. Zhao, A.; Zhao, C.; Ren, J.; Qu, X. Enantioselective targeting left-handed Z-G-quadruplex. Chem. Commun. 2016, 52, 1365-1368. [CrossRef]

58. Zhao, C.; Song, H.; Scott, P.; Zhao, A.; Tateishi-Karimata, H.; Sugimoto, N.; Ren, J.; Qu, X. Mirror-Image Dependence: Targeting Enantiomeric G-Quadruplex DNA Using Triplex Metallohelices. Angew. Chem. Int. Ed. 2018, 57, 15723-15727. [CrossRef]

59. Balasubramanian, S.; Hurley, L.H.; Neidle, S. Targeting G-quadruplexes in gene promoters: A novel anticancer strategy? Nat. Rev. Drug Discov. 2011, 10, 261-275. [CrossRef] [PubMed]

60. Diveshkumar, K.V.; Sakrikar, S.; Harikrishna, S.; Dhamodharan, V.; Pradeepkumar, P.I. Targeting Promoter G-Quadruplex DNAs by Indenopyrimidine-Based Ligands. ChemMedChem 2014, 9, 2754-2765. [CrossRef] 
61. Catz, S.D.; Johnson, J.L. BCL-2 in prostate cancer: A minireview. Apoptosis 2003, 8, 29-37. [CrossRef]

62. Sengupta, P.; Chattopadhyay, S.; Chatterjee, S. G-Quadruplex surveillance in BCL-2 gene: A promising therapeutic intervention in cancer treatment. Drug Discov. Today 2017, 22, 1165-1186. [CrossRef]

63. Pengo, P.; Pantoş, G.D.; Otto, S.; Sanders, J.K.M. Efficient and Mild Microwave-Assisted Stepwise Functionalization of Naphthalenediimide with $\alpha$-Amino Acids. J. Org. Chem. 2006, 71, 7063-7066. [CrossRef]

64. Howard, F.B.; Miles, H.T. Poly(inosinic acid) helixes: Essential chelation of alkali metal ions in the axial channel. Biochemistry 1982, 21, 6736-6745. [CrossRef]

65. Kerkour, A.; Marquevielle, J.; Ivashchenko, S.; Yatsunyk, L.A.; Mergny, J.-L.; Salgado, G.F. High-resolution three-dimensional NMR structure of the KRAS proto-oncogene promoter reveals key features of a G-quadruplex involved in transcriptional regulation. J. Biol. Chem. 2017, 292, 8082-8091. [CrossRef]

66. Dettler, J.M.; Lewis, E.A. Biophysical Studies of the Structure, Stability, and Ligand Binding Properties of G-Quadruplex DNA: Thoughts and Comparisons of the K-ras, c-MYC, and Bcl-2 Oncogene Promoter Sequence Quadruplexes. In Frontiers in Nucleic Acids; Sheardy, R.D., Winkle, S.A., Eds.; American Chemical Society: Washington, DC, USA, 2011; Volume 1082, pp. 33-50. ISBN 978-0-8412-2623-4.

67. Kuryavyi, V.; Phan, A.T.; Patel, D.J. Solution structures of all parallel-stranded monomeric and dimeric G-quadruplex scaffolds of the human c-kit2 promoter. Nucleic Acids Res. 2010, 38, 6757-6773. [CrossRef]

68. Chang, T.; Qi, C.; Meng, J.; Zhang, N.; Bing, T.; Yang, X.; Cao, Z.; Shangguan, D. General Cell-Binding Activity of Intramolecular G-Quadruplexes with Parallel Structure. PLoS ONE 2013, 8, e62348. [CrossRef]

69. Xu, Y.; Noguchi, Y.; Sugiyama, H. The new models of the human telomere d[AGGG(TTAGGG)3] in K+ solution. Bioorg. Med. Chem. 2006, 14, 5584-5591. [CrossRef]

70. Ambrus, A.; Chen, D.; Dai, J.; Bialis, T.; Jones, R.A.; Yang, D. Human telomeric sequence forms a hybrid-type intramolecular G-quadruplex structure with mixed parallel/antiparallel strands in potassium solution. Nucleic Acids Res. 2006, 34, 2723-2735. [CrossRef]

71. Dai, J.; Carver, M.; Punchihewa, C.; Jones, R.A.; Yang, D. Structure of the Hybrid-2 type intramolecular human telomeric G-quadruplex in $\mathrm{K}^{+}$solution: insights into structure polymorphism of the human telomeric sequence. Nucleic Acids Res. 2007, 35, 4927-4940. [CrossRef]

72. Dai, J.; Punchihewa, C.; Ambrus, A.; Chen, D.; Jones, R.A.; Yang, D. Structure of the intramolecular human telomeric G-quadruplex in potassium solution: a novel adenine triple formation. Nucleic Acids Res. 2007, 35, 2440-2450. [CrossRef]

73. Phan, A.T.; Kuryavyi, V.; Luu, K.N.; Patel, D.J. Structure of two intramolecular G-quadruplexes formed by natural human telomere sequences in $\mathrm{K}^{+}$solution. Nucleic Acids Res. 2007, 35, 6517-6525. [CrossRef]

74. Luu, K.N.; Phan, A.T.; Kuryavyi, V.; Lacroix, L.; Patel, D.J. Structure of the Human Telomere in $\mathrm{K}^{+}$Solution: An Intramolecular (3 + 1) G-Quadruplex Scaffold. J. Am. Chem. Soc. 2006, 128, 9963-9970. [CrossRef]

75. Wen, L.-N.; Xie, M.-X. Evidence of different G-quadruplex DNA binding with biogenic polyamines probed by electrospray ionization-quadrupole time of flight mass spectrometry, circular dichroism and atomic force microscopy. Biochimie 2013, 95, 1185-1195. [CrossRef]

76. Wang, C.; Yu, Q.; Yang, L.; Liu, Y.; Sun, D.; Huang, Y.; Zhou, Y.; Zhang, Q.; Liu, J. Ruthenium (II) polypyridyl complexes stabilize the bcl-2 promoter quadruplex and induce apoptosis of Hela tumor cells. BioMetals 2013, 26, 387-402. [CrossRef]

77. Xiong, Y.-X.; Chen, A.-C.; Yao, P.-F.; Zeng, D.-Y.; Lu, Y.-J.; Tan, J.-H.; Huang, Z.-S.; Ou, T.-M. Blocking the binding of WT1 to bcl-2 promoter by G-quadruplex ligand SYUIQ-FM05. Biochem. Biophys. Rep. 2016, 5, 346-352. [CrossRef]

78. Cheng, Y.; Tang, Q.; Li, Y.; Zhang, Y.; Zhao, C.; Yan, J.; You, H. Folding/unfolding kinetics of G-quadruplexes upstream of the P1 promoter of the human BCL-2 oncogene. J. Biol. Chem. 2019. [CrossRef]

79. Agrawal, P.; Lin, C.; Mathad, R.I.; Carver, M.; Yang, D. The Major G-Quadruplex Formed in the Human BCL-2 Proximal Promoter Adopts a Parallel Structure with a 13-nt Loop in $\mathrm{K}^{+}$Solution. J. Am. Chem. Soc. 2014, 136, 1750-1753. [CrossRef]

80. Onel, B.; Lin, C.; Yang, D. DNA G-quadruplex and its potential as anticancer drug target. Sci. China Chem. 2014, 57, 1605-1614. [CrossRef]

81. Kendrick, S.; Akiyama, Y.; Hecht, S.M.; Hurley, L.H. The i-Motif in the bcl-2 P1 Promoter Forms an Unexpectedly Stable Structure with a Unique 8:5:7 Loop Folding Pattern. J. Am. Chem. Soc. 2009, 131, 17667-17676. [CrossRef] 
82. Dai, J.; Dexheimer, T.S.; Chen, D.; Carver, M.; Ambrus, A.; Jones, R.A.; Yang, D. An Intramolecular G-Quadruplex Structure with Mixed Parallel/Antiparallel G-Strands Formed in the Human BCL-2 Promoter Region in Solution. J. Am. Chem. Soc. 2006, 128, 1096-1098. [CrossRef]

83. Terenzi, A.; Lötsch, D.; van Schoonhoven, S.; Roller, A.; Kowol, C.R.; Berger, W.; Keppler, B.K.; Barone, G. Another step toward DNA selective targeting: $\mathrm{Ni}^{\mathrm{II}}$ and $\mathrm{Cu}$ II complexes of a Schiff base ligand able to bind gene promoter G-quadruplexes. Dalton Trans. 2016, 45, 7758-7767. [CrossRef]

84. Hsu, S.-T.D.; Varnai, P.; Bugaut, A.; Reszka, A.P.; Neidle, S.; Balasubramanian, S. A G-Rich Sequence within the c-kit Oncogene Promoter Forms a Parallel G-Quadruplex Having Asymmetric G-Tetrad Dynamics. J. Am. Chem. Soc. 2009, 131, 13399-13409. [CrossRef]

Sample Availability: Samples of the compounds (NDI ligands) are available from the authors.

(C) 2019 by the authors. Licensee MDPI, Basel, Switzerland. This article is an open access article distributed under the terms and conditions of the Creative Commons Attribution (CC BY) license (http://creativecommons.org/licenses/by/4.0/). 